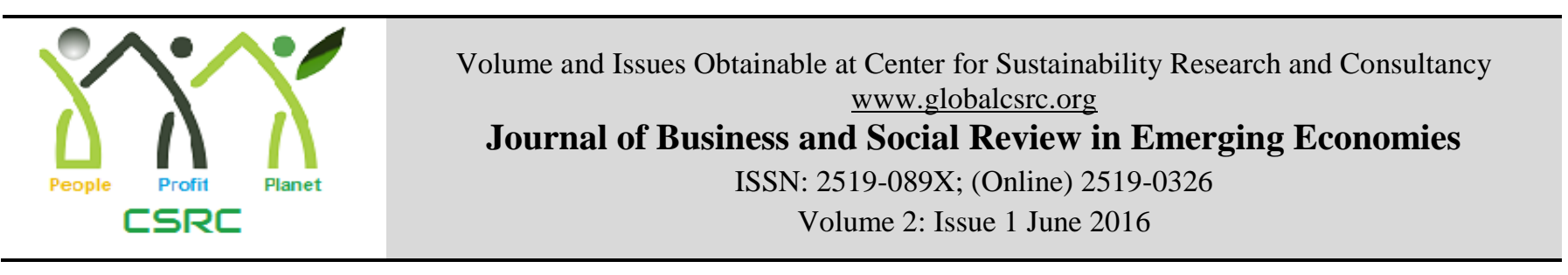

\title{
Perceived Social Support between Criminals and Non-criminals in Punjab, Pakistan
}

\author{
${ }^{1 *}$ Umbreen Khizar, ${ }^{2}$ Fatima Khurram Bukhari \\ ${ }^{1} \mathrm{Ph} . \mathrm{D}$ Scholar, School of Applied Psychology, Social work and Policy, Universiti Utara Malaysia, \\ umbreenkhizar@gmail.com \\ ${ }^{2}$ Ph.D Scholar, School of Applied Psychology, Social work and Policy, Universiti Utara Malaysia, \\ fatima.khurram@iub.edu.pk
}

\begin{tabular}{l}
\hline ARTICLE DETAILS \\
\hline History \\
Revised Format: May 2016 \\
Available Online: June 2016 \\
\\
\hline Keywords \\
Perceived social support \\
Idealism \\
Crime \\
Punjab
\end{tabular}

JEL Classification:

M11, M14,

\begin{abstract}
Objective: The purpose of this paper is to investigate the alliance performance of construction Objective: The purpose of the current research was to explore the level of perceived social support between criminals and non-criminals.
\end{abstract}

Methodology: 160 participants were considered as a sample, 80 were criminals (40 males and 40 females) and 80 were non-criminals (40 males and 40 females) taken from Sahiwal, Arifwala and Bahawalnagr. Criminals were selected from central jail Sahiwal and district jail Bahawalnagr. Their age range was between 18-70 years old. All individuals have a minimum metric qualification. To check the level of perceived social support, Multidimensional scale of perceived social support (MSPSS) was used.

Results: Results indicate that perceived social support and criminality are negatively correlated. The level of perceived social support is higher among non-criminals than criminals. The result suggests that there is no significant difference of perceived social support between males and females.

Implication: This paper gives valuable information about the importance of social support. Without proper support and guidance no child, no male or female will learn life skills or grow up with a strong sense of right and wrong and respect other people.

(C) 2016 The authors, under a Creative Commons AttributionNonCommercial 4.0

\section{Introduction}

Social support is genuine help or a sentimental connection given by societal associations or connections and is seen as loving or adoring. Through maturity an expanded measure of time is spent outside the family and individual partakes in community exercises so it is essential that how he sees his encompassing surroundings. A person's societal emotionally supportive network incorporates associates, loved ones. The individuals who believe their families and have solid associations with them have been seen to keep up great associations with their companions too. Accepting bolster offers intending to *Corresponding author's email address: umbreenkhizar@gmail.com

Recommended citation: Khizer, U. and Khurram, F. (2016). Perceived social support between criminals and non-criminals in Punjab, Pakistan. Journal of Business and Social Review in Emerging Economies, 2 (1) 87-91. DOI: https://doi.org/10.26710/jbsee.v2i1.22 
people's lives by excellence of propelling them to give consequently, to feel committed, and to be appended to their ties. Close and loving connections give support to a person when he is down. These connections offer chances to express and to get love, both of which are vital for personality, self-esteem and self-regard (Aydin, 2005).

The recognition that an interpersonal organization is strong supports one's self-assurance and accomplishes sought objectives. Steady social connections give aptitudes important to modify with changing standards and estimations of a general public. Individuals who report that their family is strong had all the earmarks of being capable and have versatile qualities. A developing assortment of writing recommends that steady social connections may impact scholarly accomplishment in a roundabout way through motivational and full of feeling components (Eccles, 2007; Roeser, Eccles, \& Sameroff, 2000).

Parental conduct and dispositions and environment of the personal household may all impact views of a man about social support. Irritated family life, poor training and informal organization and high joblessness are all elements which add to wrongdoing. Cultural morals and encompassing conditions are likewise critical. Conditions that encompass the way a person or a group lives make defenseless to a man to carry out wrongdoing. Individuals that serve utilitarian parts in the criminal' $\mathrm{s}$ life are viewed as possessions. The criminal has his own arrangement of ethics, for customary ones don't fundamentally apply. Since the things are not viewed by criminals from other people's point of view, his passionate venture to family is negligible. Schreck and Fisher, (2004) stated that guardians and family, along these lines, fill an utilitarian need for the criminal. Remarking on their discoveries with respect to family qualities that influence powerlessness to brutal adolescent exploitation, researchers reasoned that there is an opportunity that helplessness to wrongdoing is a "period stable individual characteristic" foreordained by family socialization.

Financial position of family or locality is connected with culpability or introverted conduct in youngsters. Living in a urban home, having a low financial status, or poor social abilities can lead a person to being unsuccessful in achieving their needs in a socially alluring manner, which can transform into withdrawn or criminal conduct. The young ladies and young men who need to work for cash are more presented to the criminal exercises and along these lines carry out them more (Ramchand et al, 2009).

\section{Hypotheses of the Study}

- Level of perceived social support in criminals would be low than non-criminals.

- Females would have less perceived social support than males.

\section{Method}

Total 160 individuals were considered as a sample, 80 were criminals (40 males and 40 females) and 80 were non-criminals (40 males and 40 females). To select criminals, central jail of Sahiwal and district jail Bahawalnagr were approached. These regions of Punjab were also selected for non-criminals. The age of all participants was between 18 to 70 years. All participants have at least metric qualification. The convenience sampling method and random sampling method were used to select the criminals and non-criminals.

\section{Instruments}


In order to measure level of perceived social support the Multidimensional Scale of Perceived Social Support (MSPSS) was used and the presence of emotional and behavioral problems have correlation with positive or negative perception of social support.

\section{Procedure}

The sample was consisted of 160 individuals. Firstly, permissions from the jails management was approved to carry out the research. Before beginning the research the informed consensus of all the members was gained. They were guaranteed that their data would be reserved classified and the information will be utilized just for research reason.

The scale was Multidimensional Scale of Perceived Social Support (MSPSS) When the questionnaires were filled by members, each questionnaire was then checked independently and the scoring guide was used for rating.

\section{Result}

Comparison of perceived social support between criminals and non-criminals. $(N=160)$

\begin{tabular}{|c|c|c|c|c|c|c|c|c|c|}
\hline & \multicolumn{2}{|c|}{$\begin{array}{l}\text { Levene's } \\
\text { Test for } \\
\text { Equality of } \\
\text { Variances }\end{array}$} & & \multicolumn{4}{|c|}{ t-test for Equality of Means } & \multicolumn{2}{|c|}{$\begin{array}{c}95 \% \\
\text { Confidence } \\
\text { Interval of the } \\
\text { Difference }\end{array}$} \\
\hline & $\mathrm{F}$ & Sig. & $\mathrm{t}$ & $\mathrm{df}$ & $\begin{array}{l}\text { Sig. }(2- \\
\text { tailed })\end{array}$ & $\begin{array}{c}\text { Mean } \\
\text { Difference }\end{array}$ & $\begin{array}{l}\text { Std. Error } \\
\text { Difference }\end{array}$ & Lower & Upper \\
\hline $\begin{array}{l}\text { Equal } \\
\text { variances } \\
\text { assumed }\end{array}$ & .022 & .882 & -5.892 & 158 & .000 & -10.487 & 1.780 & -14.003 & -6.972 \\
\hline
\end{tabular}

Results showed that significance level of this test is 0.000 that is less than significance level of 0.05 $(\mathrm{p}<0.05)$. So, this hypothesis is accepted. It is concluded that non-criminals have high level of perceived social support than criminals.

Comparison of Perceived social support between Males and Females.

\begin{tabular}{|c|c|c|}
\hline Levene's & & $95 \%$ Confidence \\
\hline Equality of & & Interval of the \\
\hline Variances & t-test for Equality of Means & Difference \\
\hline
\end{tabular}




\begin{tabular}{|c|c|c|c|c|c|c|c|c|c|}
\hline & & & & & $\begin{array}{l}\text { Sig. } \\
(2- \\
\text { tailed }\end{array}$ & $\begin{array}{c}\text { Mean } \\
\text { Differen }\end{array}$ & $\begin{array}{c}\text { Std. } \\
\text { Error } \\
\text { Differen }\end{array}$ & & \\
\hline & $\mathrm{F}$ & Sig. & $\mathrm{t}$ & $\mathrm{df}$ & ) & ce & ce & Lower & Upper \\
\hline $\begin{array}{l}\text { Equal } \\
\text { variances } \\
\text { assumed }\end{array}$ & .242 & .624 & $\begin{array}{l}1.4 \\
53\end{array}$ & 158 & .148 & -2.837 & 1.953 & -6.694 & 1.019 \\
\hline
\end{tabular}

Results showed that significance level of this test is .148 that is more than the significance level of 0.05 ( $>$ 0.05). So, this hypothesis that males have higher perceived social support is rejected. No significant difference of perceived social support is found between males and females.

\section{Conclusion}

This study concluded that perceived social support and criminality are negatively correlated. People with higher perceived social support are more averse to perpetrate wrongdoings. The outcomes likewise demonstrate that there is no noteworthy difference of perceived social support amongst males and females.

\section{Discussion}

The results confirmed the first hypothesis and concluded a low level of perceived social support in criminals as compared to non-criminals counterparts. The individual has more vulnerability to commit crime if perceived social support level is low. Social support helps the individual to manage better with a distressing condition. Sarason et al., (1983) stated that people high in perceived social support are likewise more constructive and tend to report more constructive life rehearses and more prominent control over their lives than their low partners.

The other hypothesis was related to the correlation between gender and perceived social support. The results found high level of perceived social support among females as compared to males. Gender has impact on perceived social support. This research concludes different results it might be because of test qualities or social contrasts on the grounds that in a few social orders, females have less fulfillment, less chances to associate with others when contrasted with males and less perceived social support. Taylor (1988) contemplated that the unhappy women are less satisfied and have down levels of social support than depressed men.

\section{References}

Andrews, D. A., \& Bonta, J. (2006). The Psychology of Criminal Conduct. Newark, NJ: Andersos.

Aydın, B. (2005). Çocuk ve ergen psikolojisi [Child and adolescent psychology]. İstanbul: Atlas Publishing.

Eccles, J. S. (2007). Families, Schools, and Developing Achievement-related Motivations and Engagement. In J. E. Grusec \& P. D. Hastings (Eds.), Handbook of Socialization (pp. 665-691). New York, NY: The Guilford Press.

Ramchand, R., Elliott, M. N., Mrug, S., Grunbaum, J. A., Windle, M., Chandra, A., Peskin, M. F., Cooper, S. P., \& Schuster, M. A. (2009). Substance use and Delinquency Among Fifth Graders 
Who have Jobs. American Journal of Preventive Medicine, 36, 297-303.

Roeser, R. W., Eccles, J. S., \& Sameroff, A. J. (2000). School as a Context of early Adolescents' Academic and Social-emotional Development: A Summary of Research Findings. The Elementary School Journal, 100, 443-471.

Sarason, I. G., Sarason, G. R., Levine, H. M., Basham, R. B., \& Sarason, B. R. (1983). Assessing Social Support: The Social Support Questionnaire. Journal of Personality and Social Psychology, 44, 127-139.

Schreck, C. J., \& Fisher, B. S. (2004). Specifying the influence of family and peers on violent victimization: Extending routine and lifestyles theories. Journal of Interpersonal Violence, 19, 1021-1041.

Taylor, B. (1988). Illusion and Well-being: A Social Psychological Perspective on Mental Health. Psychological Bulletin, 103, 193-210. 